RESEARCH PAPER RP1107

Part of Journal of Research of the National Bureau of Standards, Volume 20, June 1938

\title{
HEATS OF HYDRATION AND TRANSITION OF CALCIUM SULFATE
}

\author{
By Edwin S. Newman and Lansing S. Wells
}

\section{ABSTRACT}

The heats of solution at $25^{\circ} \mathrm{C}$ in 2.09 molal $\mathrm{HCl}$ of gypsum, hemihydrate, natural anhydrite, and anhydrous $\mathrm{CaSO}_{4}$, prepared by heating gypsum at various temperatures, have been determined. From these values the heats evolved in the hydration to gypsum of hemihydrate, and of anhydrite prepared at $1,000^{\circ} \mathrm{C}$, were calculated to be $4,100 \pm 30$ and $3,990 \pm 20 \mathrm{cal} / \mathrm{mole}$, respectively. The heat evolved in the hydration to gypsum of soluble anhydrite prepared by dehydrating gypsum at $75^{\circ} \mathrm{C}$ is not less than $6,990 \mathrm{cal} / \mathrm{mole}$. In the course of this work X-ray and microscopic studies gave no indication of the existence of more than two forms of anhydrous calcium sulfate: Soluble anhydrite and a modification formed rapidly at high temperatures, the latter being identical with natural anhydrite. The heat evolved in the transition of soluble anhydrite to natural anhydrite is not less than $3,000 \mathrm{cal} / \mathrm{mole}$.

\section{CONTENTS}

I. Introduction

II. Preparation of materials

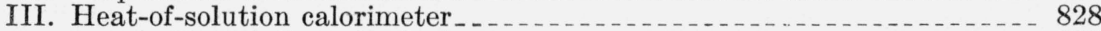

1. Description of calorimeter $\ldots \ldots 28$

2. Calculations

IV. Experimental results and discussion

1. Heats of solution .

2. X-ray diffraction patterns

3. Microscopic examination 834

4. Heats of hydration and transition

V. Summary

VI. References

\section{INTRODUCTION}

Despite the fact that calcium sulfate and its hydrates have been the subject of many investigations, considerable confusion has existed as to the number of forms and their energy relations. There has also grown up a perplexing terminology. It is universally agreed that gypsum, $\mathrm{CaSO}_{4} \cdot 2 \mathrm{H}_{2} \mathrm{O}$, and natural anhydrite, $\mathrm{CaSO}_{4}$, are distinct compounds. On the other hand, there has been considerable difference of opinion about the anhydrous forms resulting from the dehydration of gypsum and hemihydrate at various temperatures and as to whether or not hemihydrate, $\mathrm{CaSO}_{4} \cdot 1 / 2 \mathrm{H}_{2} \mathrm{O}$, is a definite compound.

Van't Hoff [1] ${ }^{1}$ originated the term "soluble anhydrite" to describe the anhydrous form prepared from gypsum at low temperatures, and

\footnotetext{
1 Numbers in brackets refer to literature citations at the end of this paper.
} 
distinguish it from the less soluble anhydrous forms, "dead-burned gypsum" and the naturally occurring anhydrite.

Jung [2], Ramsdell and Partridge [3], and Caspari [4] consider that hemihydrate is a zeolite, basing their conclusions on the fact that X-ray diffraction patterns of the hemihydrate which they secured were identical with those of the products obtained by dehydrating hemihydrate. Thus there arose the term "dehydrated hemihydrate." Feitknecht [5], on the other hand, observed differences in the patterns of hemihydrate and its dehydration product, provided rehydration of the latter was prevented. Onorato [6] and Gallitelli [7] likewise detected differences in the patterns. More recently, Weiser, Milligan, and Ekholm $[8,9]$, and Posjnak [10] have obtained patterns that leave little doubt that hemihydrate and the anhydrous material resulting from its dehydration at relatively low temperature are different in structure. Since the term "soluble anhydrite" has the advantages of conciseness and prior usage it takes the place in this paper of the more cumbersome "dehydrated hemihydrate" of recent authors to indicate the low-temperature, unstable dehydration product of either gypsum or hemihydrate.

TABLE 1.-Previously reported heats of hydration to gypsum of $\mathrm{CaSO}_{4} \cdot 1 / 2 \mathrm{H}_{2} \mathrm{O}$ and $\mathrm{CaSO}_{4}$

\begin{tabular}{|c|c|c|c|c|c|c|}
\hline Investigator & $\begin{array}{l}\text { Litera- } \\
\text { ture } \\
\text { refer- } \\
\text { ence }\end{array}$ & $\begin{array}{c}\text { Heat of } \\
\text { hydra- } \\
\text { tion to } \\
\text { gypsum } \\
\text { of } \\
\mathrm{CaSO}_{4} . \\
1 / 2 \mathrm{H}_{2} \mathrm{O}\end{array}$ & $\begin{array}{l}\text { Method of } \\
\text { preparation }\end{array}$ & $\begin{array}{c}\text { Heat of } \\
\text { hydra- } \\
\text { tion to } \\
\text { gypsum } \\
\text { of } \\
\mathrm{CaSO}_{4}\end{array}$ & $\begin{array}{c}\text { Method of } \\
\text { preparation }\end{array}$ & $\begin{array}{l}\text { Method for deter- } \\
\text { mining heat of } \\
\text { hydration }\end{array}$ \\
\hline Thomsen... & [17] & cal/mole & & $\underset{4,740}{\mathrm{cal} / \mathrm{mole}}$ & $\begin{array}{l}\text { Gypsum heated at } \\
120^{\circ} \mathrm{C} \text {. }\end{array}$ & $\begin{array}{l}\text { Direct hydration } \\
\text { in calorimeter. }\end{array}$ \\
\hline Van't Hoff.. & [1] & 3,921 & $\begin{array}{l}\text { Gypsum dehy- } \\
\text { drated in NaCl } \\
\text { solution. } \\
\text { Gypsum heated to }\end{array}$ & 4,606 & $\begin{array}{l}\text { Natural anhydrite. } \\
\text { Gypsum heated } 4\end{array}$ & $\begin{array}{l}\text { Application of } \\
\text { Clausius-Clapey- } \\
\text { ron equation to } \\
\text { vapor-pressure } \\
\text { data. }\end{array}$ \\
\hline de Forcrand.. & [18] & 3,860 & $\left\{\begin{array}{l}\text { constant weight } \\
\text { at } 110^{\circ} \mathrm{C} \text { (3 to } \\
4 \mathrm{hr}) .\end{array}\right.$ & 3,220 & $\begin{array}{l}\text { hr at } 155^{\circ} \mathrm{C} \text {. } \\
\text { Above material } \\
\text { heated } 15 \text { min- }\end{array}$ & $\begin{array}{l}\text { Heat of solution } \\
\text { in water. }\end{array}$ \\
\hline Mixter & [19] & & & 4,500 & $\begin{array}{l}\text { Gypsum heated to } \\
\text { constant weight } \\
\text { at } 160 \text { and } 200^{\circ} \mathrm{C} \text {. }\end{array}$ & $\begin{array}{l}\text { Heat of fusion with } \\
\mathrm{Na}_{2} \mathrm{O}_{2} \text { and } \mathrm{C} \text { or } \\
\mathrm{S} \text {. }\end{array}$ \\
\hline Chassevent_... & {$[20]$} & 3,800 & $\begin{array}{l}\text { Gypsum heated in } \\
\text { steam at } 140^{\circ} \mathrm{C} .\end{array}$ & 6,570 & $\begin{array}{l}\text { Gypsum heated at } \\
200^{\circ} \mathrm{C} \text {. }\end{array}$ & $\begin{array}{l}\text { Direct hydration } \\
\text { in calorimeter. }\end{array}$ \\
\hline Olson & [35] & & & $\begin{array}{l}6,730 \\
4,850\end{array}$ & $\begin{array}{l}\text { Gypsum heated at } \\
140^{\circ} \mathrm{C} \text {. } \\
\text { Gypsum heated } 1\end{array}$ & $\begin{array}{l}\text { Direct hydration } \\
\text { in calorimeter. }\end{array}$ \\
\hline Budnikov.... & [16] & & & & $\begin{array}{l}\text { hr at } 200^{\circ} \mathrm{C} . \\
\text { Gypsum heated } 1 \\
\text { hr at } 750^{\circ} \mathrm{C} \text {. }\end{array}$ & $\begin{array}{l}\text { Direct hydration } \\
\text { in calorimeter. }\end{array}$ \\
\hline
\end{tabular}

Certain investigators have suggested the existence of other anhydrous forms of calcium sulfate. LaCroix [11] reported a triclinic modification formed when gypsum was heated slowly to $125^{\circ} \mathrm{C}$ and a hexagonal form appeared above $255^{\circ} \mathrm{C}$. Both of these, he declared, were different from natural anhydrite, to which they changed upon heating to a bright-red heat. Gaubert [12] described three anhydrites, gamma-anhydrite formed below $170^{\circ} \mathrm{C}$, beta-anhydrite at about this temperature, and alpha-anhydrite at about $520^{\circ}$ C. Jolibois [13] 
recognized an active form produced below $350^{\circ} \mathrm{C}$ and an inactive form above that temperature. Chassevent [14] believed that alpha$\mathrm{CaSO}_{4}$ existed below and beta-CaSO${ }_{4}$ above $300^{\circ} \mathrm{C}$, while Grahmann [15] applied the same terms to those forms existing above and below $1,195^{\circ} \mathrm{C}$, and reported a melting point of $\mathrm{CaSO}_{4}$ of $1,450^{\circ} \mathrm{C}$. Budnikov [16] states that dissociation to $\mathrm{CaO}$ and $\mathrm{SO}_{3}$ begins at $750^{\circ} \mathrm{C}$.

Much of the confusion appears to have arisen from failure to attain equilibrium and from acceptance of the properties of a partially converted mixture as those of a new phase. For the same reasons, the thermochemical data also present anomalies which are evident from the values of the heat of hydration listed in table 1.

In the study herein described the energy relations of various forms of calcium sulfate and its hydrates were determined by means of their heats of solution in hydrochloric acid.

\section{PREPARATION OF MATERIALS}

Gypsum was prepared by two methods: (1) By crystallization from its supersaturated solution (obtained by dissolving hemihydrate in distilled water) and (2) by precipitation from a mixture of approximately equal volumes of 10 -percent solutions of reagent quality calcium chloride and sulfuric acid. The preparations were thoroughly washed with distilled water, alcohol, and ether, and the residual ether was allowed to evaporate spontaneously. Seven preparations were made in all. The one finally selected for extended investigation had a loss on ignition of 20.98 percent (theoretical $=20.93$ percent) and microscopic examination disclosed no foreign material.

The samples of hemihydrate used in this work were prepared by heating $2.000 \mathrm{~g}$ of the gypsum, contained in weighed open Pyrex glass capsules, in steam for 3 hours at $115 \mathrm{lb} /$ in $^{2}$ absolute pressure. The material was next dried in the open capsule approximately 18 hours at $75^{\circ} \mathrm{C}$ and then allowed to stand exposed to the laboratory air until the heat of solution was determined. Water content as indicated by the loss in weight varied from 6.16 to 6.30 percent (theoretical $=6.21$ percent). The material had refractive indices corresponding to those reported for hemihydrate [21] and no other material was detected.

Anhydrous calcium sulfate was prepared by heating gypsum in an electric furnace at temperatures ranging from 75 to $1,225^{\circ} \mathrm{C}$ for times ranging from 5 months to 10 minutes. For the sample prepared at $75^{\circ} \mathrm{C}$ the gypsum was placed in a vacuum over $\mathrm{P}_{2} \mathrm{O}_{5}$ to expedite dehydration. At temperatures below $700^{\circ} \mathrm{C}$, samples weighing $2.000 \mathrm{~g}$ were heated in weighed glass capsules which, immediately after cooling and weighing, were closed with sealing wax and a cover glass. At $700^{\circ} \mathrm{C}$ and above the gypsum was heated in platinum and kept in tightly corked vials. Approximately 0.2 percent of water (as indicated by loss in weight) remained in the samples prepared at $300^{\circ} \mathrm{C}$ and below, but at higher temperatures the resulting $\mathrm{CaSO}_{4}$ was anhydrous.

Natural anhydrite, from Midland, Calif., was ground to pass a No. 200 sieve. Determinations of $\mathrm{SiO}_{2}, \mathrm{Al}_{2} \mathrm{O}_{3}, \mathrm{Fe}_{2} \mathrm{O}_{3}$, and $\mathrm{MgO}$ indicated that the total of these materials did not exceed 0.5 percent and the loss on ignition was 1.6 percent. The refractive indices corresponded with those reported [22], and no material other than natural anhydrite was detected microscopically. 


\section{HEAT-OF-SOLUTION CALORIMETER}

\section{DESCRIPTION OF CALORIMETER}

The calorimeter used was developed at the National Bureau of Standards for determining the heat of solution of cement and is of the type described by Woods [23], Biddle [24], and Stenzel [25]. The

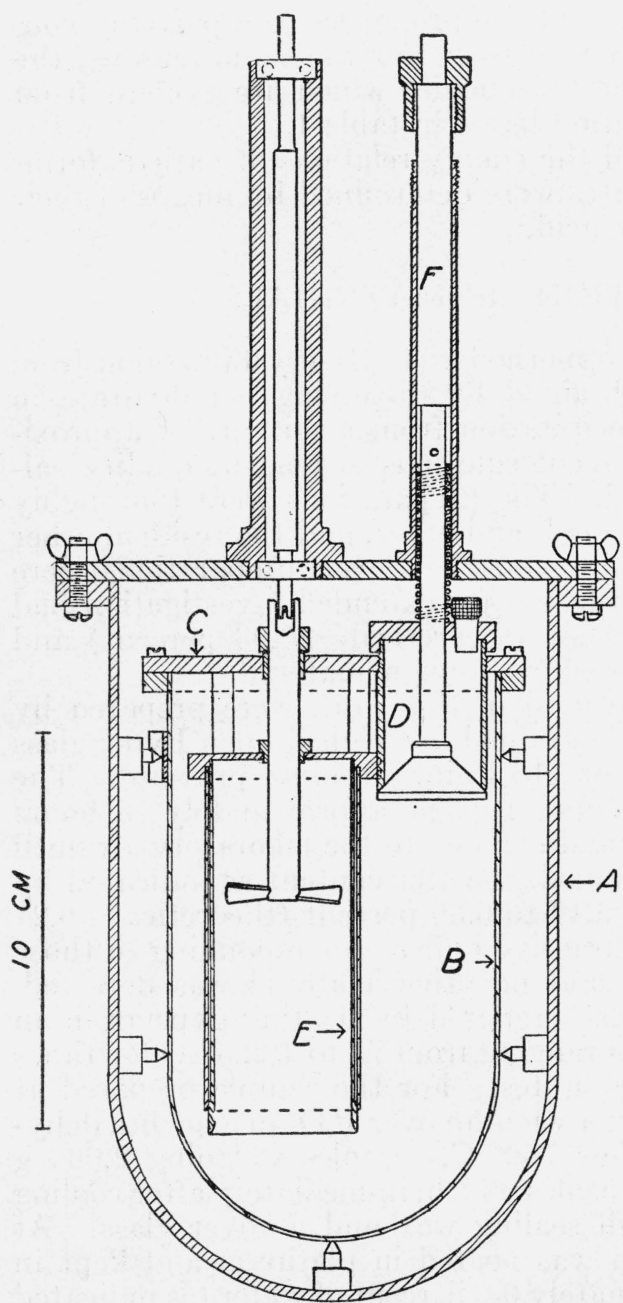

Figure 1.-Heat-of-solution calorimeter. calorimeter, ${ }^{2}$ shown in figure 1 , consists of a reaction vessel, $B$, and an outer watertight jacket, $A$. Chimneys in the jacket lid (only two of which appear in fig. 1) are provided for the thermometer, heater leads, stirrer shaft, and valve stem. The lid, $C$, of the reaction vessel supports a Bakelite sample valve, $D$, and a hollow cylindrical heating unit, $E$, which served also as a stirring tube. All metallic surfaces within the reaction vessel are protected with an acid-resisting vinyl resin lacquer. A clear Bakelite propeller within the stirring tube, driven by a synchronous motor, provides the stirring. The heater is constructed of two close-fitting coaxial cylinders soldered together at the bottom and to the supporting ring at the top. A noninductive resistance of manganin wire is wound in the annular space provided by a recess in the inner cylinder, and the leads are brought out through a channel in the supporting ring and one of the pillars to the corresponding chimney in the jacket. The sample container, $D$, is a hollow cylinder of clear Bakelite closed at the lower end by a mushroom valve of the same material, and at the $A$, outer jacket; $B$, reaction vessel; $C$, cover of reaction vessel; upper end by a black Bake$D$, valve for introduction of sample; $E$, heater coil; $F$, rod for opening valve.

lite cap supporting the valve stem and spring. The valve stem extends into one of the exit chimneys in the lid of the outer vessel. The outside of the chimney is threaded at the upper end and a threaded bushing bearing against a shoulder on a Bakelite rod, $F$, is screwed down over these threads to open the valve. The sample is placed

${ }^{2}$ Complete details of construction are described in U. S. Bureau of Reclamation Specification 566 for Cement for Boulder Dam. 
in the valve cylinder while the calorimeter is being assembled and is introduced into the acid charge by opening the valve after the calorimeter has been placed in the constant-temperature bath and the rate of temperature rise caused by stirring and thermal leakage has reached a constant value. The temperature of the calorimeter is measured with a 25 -ohm platinum resistance thermometer incased in a platinum sheath and a Mueller temperature bridge.

The acid charge used in this work was $640.0 \mathrm{~g}$ of $2.09 \mathrm{molal}^{3}$ hydrochloric acid in water. During a determination the calorimeter was immersed in a water bath controlled automatically at 25.000 $\pm .005^{\circ} \mathrm{C}$. The heat capacity of the calorimeter and contents was measured by introducing a measured amount of electrical energy and measuring the resultant temperature rise. The factor used in converting the international joule to the conventional defined calorie [27] is 4.1833 . The heat capacity of the calorimeter and contents and the characteristics of the measuring system were such that on a scale $1.5 \mathrm{~m}$ from the galvanometer a deflection of $1 \mathrm{~mm}$ was equivalent to 0.26 calorie. Deflections were estimated to $0.25 \mathrm{~mm}$, equivalent to $0.00001 \mathrm{ohm}$ or $0.0001^{\circ} \mathrm{C}$. Changes in resistance of $0.0001 \mathrm{ohm}$ (equivalent to $0.001^{\circ} \mathrm{C}$ ) could be read directly on the bridge dials. The resistance-temperature coefficient of the thermometer was 0.1010 at $25^{\circ} \mathrm{C}$, the temperature of the experiments. The calorimeter samples were of such size that they contained anhydrous $\mathrm{CaSO}_{4}$ equivalent to $2.000 \mathrm{~g}$ of $\mathrm{CaSO}_{4} \cdot 2 \mathrm{H}_{2} \mathrm{O}$. Samples of precipitated gypsum, natural anhydrite, and anhydrous $\mathrm{CaSO}_{4}$ prepared at temperatures of $700^{\circ} \mathrm{C}$ and above were introduced by means of the Bakelite valve; those of hemihydrate and anhydrous $\mathrm{CaSO}_{4}$ prepared below $700^{\circ} \mathrm{C}$, by removing the valve, substituting the capsule, and crushing it against the bottom of the calorimeter.

\section{CALCULATIONS}

The temperature changes observed in the calorimetric determinations were corrected by the "Second Geophysical Laboratory Formula" given by White [26].

The percentage "energy equivalent error" [27], $a$, of the heatcapacity measurements of the calorimeter was calculated by the formula

$$
a= \pm(100) \frac{2 \sqrt{\sum v^{2} / m(m-1)}}{\text { (value of energy equivalent) }},
$$

in which $\sum v^{2}$ is the sum of the squares of the deviations from the arithmetical mean of $m$ experimental values.

Likewise, the percentage "reaction error", $b$, was calculated by the formula

$$
b= \pm(100) \frac{2 \sqrt{\sum v^{2} / n(n-1)}}{\text { (value of reaction energy) }},
$$

in which $n$ is the number of determinations of the heat of solution.

The final assigned "precision error" ${ }^{4}$ of the average value for the heat of solution is

$$
\text { "precision error" }= \pm \sqrt{a^{2}+b^{2}} .
$$

\footnotetext{
${ }^{3}$ A molal solution is one containing 1 gram-molecule of solute per $1,000 \mathrm{~g}$ of solvent.
}

- The energy equivalent error of the heat capacity was \pm 0.034 percent. 
The last equation is also used to calculate the error of the sum or difference of two heats of solution $A$ and $B$ affected with errors $a$ and $b$, but the errors in this case must be expressed in calories and not in percentages.

\section{EXPERIMENTAL RESULTS AND DISCUSSION}

\section{HEATS OF SOLUTION}

The average of 21 determinations of the heat of solution of five preparations of gypsum was $-33.01 \mathrm{cal} / \mathrm{g} \pm 0.20$ percent. This value, equivalent to $-5,678 \mathrm{cal} / \mathrm{mole}$, was used in calculations of the heats of hydration. A sample of gypsum prepared from $\mathrm{CaCl}_{2}$ and $\mathrm{H}_{2} \mathrm{SO}_{4}$ was used for a study of the heat of solution of the products resulting from heating gypsum at different temperatures for varying lengths of time. Table 2 contains data pertaining to this preparation. The average of five determinations of the heat of solution of this sample was $-33.06 \mathrm{cal} / \mathrm{g} \pm 0.36$ percent (column 2). Column 3 shows the data pertaining to the hemihydrate, column 4 those of the material resulting from heating the gypsum at $75^{\circ} \mathrm{C}$, and columns 5 and 6 those of the materials heated at 900 and $1,000^{\circ} \mathrm{C}$, respectively. The table also contains the results of six determinations of the heat of solution of natural anhydrite (column 7).

TABLE 2.-Heats evolved in the solution of calcium sulfate and its hydrates in 2.09 molal aqueous $\mathrm{HCl}$ at $25^{\circ} \mathrm{C}^{\mathrm{a}}$

\begin{tabular}{|c|c|c|c|c|c|c|}
\hline $\begin{array}{l}\text { Determina- } \\
\text { tion num- } \\
\text { ber }\end{array}$ & $\mathrm{CaSO}_{4} \cdot 2 \mathrm{H}_{2} \mathrm{O}$ & $\mathrm{CaSO}_{4} \cdot 1 / 2 \mathrm{H}_{2} \mathrm{O}$ & $\mathrm{CaSO}_{4}{ }^{\circ}$ & $\mathrm{CaSO}_{4}^{\circ}$ & $\mathrm{CaSO}_{4}^{\mathrm{d}}$ & $\begin{array}{c}\text { Natural anhy- } \\
\text { drite }\end{array}$ \\
\hline 1 & 2 & 3 & 4 & 5 & 6 & 7 \\
\hline - & \begin{tabular}{r} 
cal $/ \mathrm{g}$ \\
-33.17 \\
-33.20 \\
-32.92 \\
-32.92 \\
-33.07 \\
\hdashline-0.0 \\
\end{tabular} & $\begin{array}{l}\mathrm{cal} / \mathrm{g} \\
-11.20 \\
-10.70 \\
-11.00 \\
-11.11 \\
-11.36 \\
-10.97 \\
-11.04\end{array}$ & $\begin{array}{r}\text { cal/g } \\
+9.27 \\
+9.52 \\
+9.42 \\
+9.42 \\
\end{array}$ & $\begin{array}{l}\text { cal/g } \\
-12.30 \\
-12.38 \\
-12.63 \\
-12.37 \\
-12.43 \\
-12.43 \\
-12.52\end{array}$ & $\begin{array}{l}\mathrm{cal} / \mathrm{g} \\
-12.80 \\
-12.85 \\
-12.80 \\
-12.54 \\
-12.75\end{array}$ & $\begin{array}{l}\text { cal/g } \\
-12.35 \\
-11.93 \\
-12.80 \\
-12.23 \\
-13.05 \\
-12.21\end{array}$ \\
\hline Average. & $-33.06 \pm .36 \%$ & $-11.05 \pm 1.4 \%$ & $+9.41 \pm 1.2 \%$ & $\pm 1.9 \%$ & $-12.75 \pm 0.86 \%$ & $-12.43 \pm 2.8 \%$ \\
\hline
\end{tabular}

a The ratio of moles of $\mathrm{CaSO}_{4}$ to $\mathrm{HCl}$ was 1 to 107 . - Heated at $75^{\circ} \mathrm{C}$ over $\mathrm{P}_{2} \mathrm{O}_{5}$.

- Heated at $900^{\circ} \mathrm{C}$.

d Heated at $1,000^{\circ} \mathrm{C}$.

The average heat of solution of the anhydrous calcium sulfate prepared at $75^{\circ} \mathrm{C}$ was $+9.41 \mathrm{cal} / \mathrm{g}$. It should be noted from figure 2, which shows the data obtained with the $\mathrm{CaSO}_{4}$ prepared from this sample of gypsum, that there was very little change, with time of heating, in the heat of solution of the product prepared at this temperature.

It is obvious from figure 2 that samples of $\mathrm{CaSO}_{4}$ prepared by heating the gypsum at different intermediate temperatures for appropriate lengths of time may have identical heats of solution.

For example, a sample heated for 10 minutes at $500^{\circ} \mathrm{C}$ had the same heat of solution as one heated 110 hours at $400^{\circ} \mathrm{C}$. This condition has often been overlooked and undoubtedly has led to some of the confusion about the energy relations of the different forms. 
The $\mathrm{CaSO}_{4}$ prepared at higher temperatures gave heats of solution less than $+9.41 \mathrm{cal} / \mathrm{g}$. Furthermore, the heat of solution decreased with increased time of heating, until, at a temperature of $900^{\circ} \mathrm{C}$, there was again very little change in the heat of solution with the time of heating. The $\mathrm{CaSO}_{4}$ prepared at $1,000^{\circ} \mathrm{C}$ also showed little or no change with the time of heating, although the heat of solution was slightly more negative $(0.31 \mathrm{cal} / \mathrm{g})$ than the average value obtained with material heated at $900^{\circ} \mathrm{C}$ (see table 2). Although this suggests that a product having a still more negative heat of solution might be obtained at a still higher temperature, nevertheless, this is doubtful

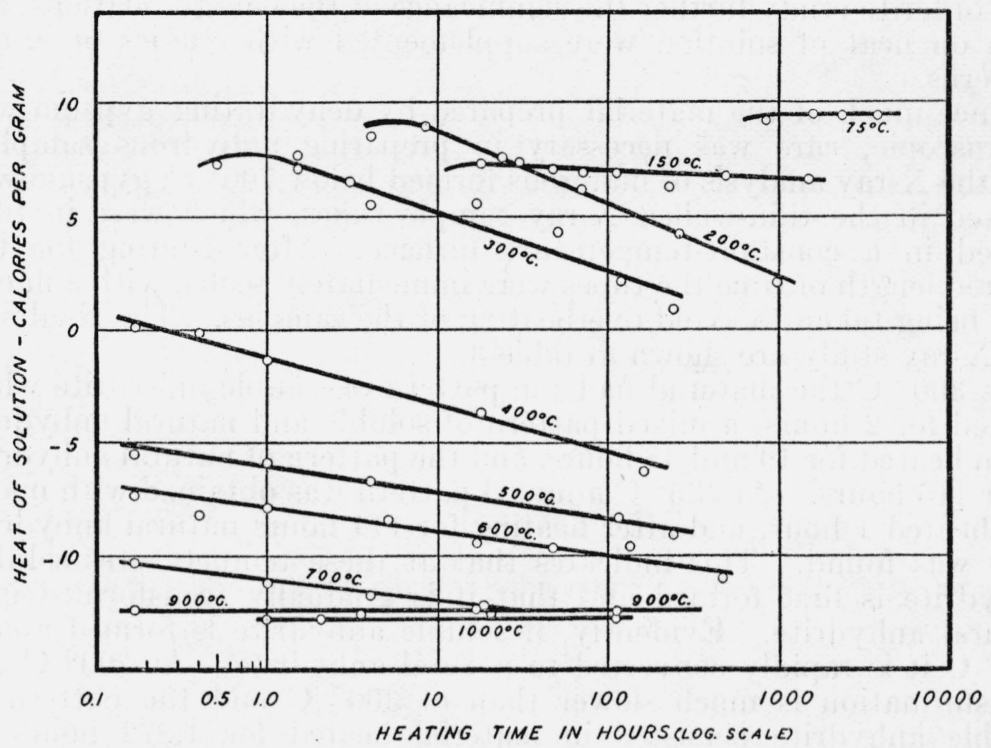

Figure 2.-Relation of heat of solution of anhydrous $\mathrm{CaSO}_{4}$ in 2.09 molal $\mathrm{HCl}$ at $25^{\circ} \mathrm{C}$ to the time and temperature of heating.

because of the dissociation which will occur at higher temperatures. Marchal [28] has determined the dissociation pressure of $\mathrm{CaSO}_{4}$ at $1,000,1,100$, and $1,230^{\circ} \mathrm{C}$ and found it to be 8,24 , and $97 \mathrm{~mm}$ of $\mathrm{Hg}$, respectively. Since the heat of solution of $1.5 \mathrm{~g}$ of $\mathrm{CaO}$ in $640 \mathrm{~g}$ of $2.09 \mathrm{molal} \mathrm{HCl}$ in this calorimeter is $+834 \mathrm{cal} / \mathrm{g}$ [29], it is evident that any dissociation of $\mathrm{CaSO}_{4}$ will result in an increase in the heat of solution. Gypsum heated at $1,100^{\circ} \mathrm{C}$ for 1,4 , and 19 hours gave heats of solution of $-11.0,+4.5$, and $+225 \mathrm{cal} / \mathrm{g}$, respectively. The corresponding free $\mathrm{CaO}^{5}$ determinations gave 0.1, 1.1, and 20.8 percent, respectively.

It is evident, from the foregoing, that no significant decrease in the heat of solution of gypsum heated to temperatures above $1,000^{\circ} \mathrm{C}$ can be directly determined by the method employed, because of the increasing amounts of free lime formed at higher temperatures. Consequently, the value $-12.67 \mathrm{cal} / \mathrm{g} \pm 0.66$ percent, the average of 19 determinations of the heat of solution of the material prepared by heating eight different preparations (including selenite, a naturally

\footnotetext{
${ }^{5}$ Free lime was determined by titration with $\mathrm{N} / 10 \mathrm{H}_{2} \mathrm{SO}_{4}$ and phenolphthalein. One-gram samples were placed in Erlenmeyer flasks with $50 \mathrm{ml}$ of $\mathrm{H}_{2} \mathrm{O}$ and boiled. Titration was considered complete when no return of color occurred with 30 minutes' boiling after the final addition of acid.
} 
occurring form) of gypsum at $1,000^{\circ} \mathrm{C}$ for times ranging from 1 to 110 hours, was chosen to calculate the heat of hydration of the high temperature modification of $\mathrm{CaSO}_{4}$.

In view of the fact that the heat of solution of the natural anhydrite (see table 2) would be made slightly less negative by the presence of impurities having an exothermic heat of solution in $\mathrm{HCl}$, the values $-12.67 \mathrm{cal} / \mathrm{g}$ for the high temperature modification and -12.43 $\mathrm{cal} / \mathrm{g}$ for the natural anhydrite are considered to be in agreement.

\section{X-RAY DIFFRACTION PATTERNS}

In order to study further the significance of the energy relations, the data on heat of solution were supplemented with studies of X-ray patterns.

Since much of the material prepared by dehydrating gypsum was hygroscopic, care was necessary in preparing anhydrous samples. For the X-ray analysis of materials formed below $700^{\circ} \mathrm{C}$, gypsum was packed in the thin-walled X-ray sample tubes, which were in turn placed in a constant-temperature furnace. After heating for the desired length of time the tubes were immediately sealed with a flame, care being taken to avoid overheating of the samples. The results of the X-ray study are shown in table 3 .

At $300^{\circ} \mathrm{C}$ the material had the pattern of soluble anhydrite when heated for 2 hours, a mixed pattern of soluble and natural anhydrite when heated for 19 and 48 hours, and the pattern of natural anhydrite after 115 hours. At $425^{\circ} \mathrm{C}$ a mixed pattern was obtained with material heated 1 hour, and after heating for 114 hours natural anhydrite only was found. This indicates that at these temperatures soluble anhydrite is first formed and that it is gradually transformed into natural anhydrite. Evidently, if soluble anhydrite is formed above $425^{\circ} \mathrm{C}$ it is rapidly converted to natural anhydrite. At $200^{\circ} \mathrm{C}$ the transformation is much slower than at $300^{\circ} \mathrm{C}$ and the pattern of soluble anhydrite persisted in material heated for 1,272 hours at $200^{\circ} \mathrm{C}$. At temperatures below $200^{\circ} \mathrm{C}$ the conversion appears to be very slow. Budnikov [30] obtained natural anhydrite by dehydrating gypsum over $\mathrm{P}_{2} \mathrm{O}_{5}$ under reduced pressure at $40^{\circ} \mathrm{C}$ but not until a year and a half had passed. That the transformation of gypsum to natural anhydrite is accelerated at low temperatures by water is indicated by the data for 170 and $210^{\circ} \mathrm{C}$ in table 3

The heats of solution of samples heated at 75 and $150^{\circ} \mathrm{C}$ (fig. 2) indicate but little change in the energy content with time of heating. At 200,300 , and $400^{\circ} \mathrm{C}$ the decrease in the heat of solution might at first thought be attributed entirely to the transformation from the soluble to the natural anhydrite, were it not for the fact that at the end of 115 hours at $300^{\circ} \mathrm{C}$ the heat of solution of the product which the X-ray pattern indicated solely as natural anhydrite was about $14 \mathrm{cal} / \mathrm{g}$ greater than that of the natural anhydrite (or the $\mathrm{CaSO}_{4}$ heated at $900^{\circ} \mathrm{C}$ ). Notwithstanding the decreases in the heat of solution of the products prepared at temperatures of $500^{\circ} \mathrm{C}$ and above, there was no change in the X-ray patterns, all of which corresponded to that of natural anhydrite. From data on heats of solution alone it would appear that the soluble anhydrite content of the samples should be from 10 to 65 percent, corresponding with heats of solution of -10 and $+2 \mathrm{cal} / \mathrm{g}$, respectively. It seems certain that the presence of such quantities of soluble anhydrite would be registered in the 
X-ray pattern, and it is difficult therefore to believe that the change in heat of solution is entirely accounted for by the transition from soluble to natural anhydrite.

TABLE 3.-X-ray diffraction patterns of $\mathrm{CaSO}_{4}$ heated at constant temperature

\begin{tabular}{|c|c|c|}
\hline $\begin{array}{c}\text { Tempera- } \\
\text { ture }\end{array}$ & $\begin{array}{l}\text { Time of } \\
\text { heating }\end{array}$ & Pattern a \\
\hline${ }^{\circ} \mathrm{C}$ & Hours & \\
\hline $110 \ldots$ & 3,670 & $S A$ \\
\hline 150 & $\begin{array}{l}170 \\
624\end{array}$ & $\begin{array}{l}S A \\
S A\end{array}$ \\
\hline 170 b. & 2,060 & $\begin{array}{l}S A \\
N A\end{array}$ \\
\hline & 3 & $S A$ \\
\hline 200 & 145 & $S A$ \\
\hline 210 b. & $\begin{array}{r}0.0 \\
44\end{array}$ & $\begin{array}{c}S A \& N A \\
N A\end{array}$ \\
\hline 300 & $\begin{array}{r}19 \\
48\end{array}$ & $\begin{array}{l}S A \& N A \\
S A \& N A\end{array}$ \\
\hline 400 & 115 & $S A \& N A$ \\
\hline 425 & $\begin{array}{r}1 \\
114\end{array}$ & $\begin{array}{c}S A \underset{N A}{\&} N A \\
N A\end{array}$ \\
\hline $\begin{array}{l}450 \ldots \\
500\end{array}$ & $1_{1 / 2}$ & $\begin{array}{l}N A \\
N A\end{array}$ \\
\hline 625 & $\begin{array}{r}1 \\
114\end{array}$ & $\begin{array}{l}N A \\
N A\end{array}$ \\
\hline $900 \ldots$ & 1 & $N A$ \\
\hline $\begin{array}{l}1,100 \\
1,225\end{array}$ & $\begin{array}{l}4 \\
2\end{array}$ & $\begin{array}{l}N A \\
N A\end{array}$ \\
\hline
\end{tabular}

a $S A$ indicates soluble anhydrite; $N A$ indicates natural anhydrite.

- Heated in contact with water.

Laschenko and Kompanskii [31] determined the densities of the products formed by heating gypsum, hemihydrate, and soluble anhydrite for 1 hour at various temperatures and found that as the materials were exposed to increased temperatures higher densities resulted. Determinations of density at $25^{\circ} \mathrm{C}$, made in this investigation, using picnometers and butyl alcohol, gave values ranging between 2.70 and $2.94 \mathrm{~g} / \mathrm{cm}^{3}$ which increased both with the time of heating and with the temperature at which the material had been heated. Since no shifts were observed in the lines of the X-ray patterns such as would accompany [32] the density changes indicated, it is felt that too much significance should not be placed on the density values obtained, especially in view of the well-known difficulties of determining accurately the density of powdered material.

The breadth of the lines in a powder X-ray pattern is a function of the constants of the apparatus and of the size of the particles in the sample. Above a certain limit an increase in particle size has little effect upon the breadth until a size is reached so large that all possible orientations are no longer present in the sample; below this limit an increase in particle size results in a gradual narrowing of the originally diffuse reflections into lines. Although there appeared to be an increase in the size of the particles upon heating (as will be mentioned particularly for material heated at $900^{\circ} \mathrm{C}$ ) the fact that the X-ray patterns did not show this effect on the breadth of the lines may be explained on the basis either that there was not an appreciable quantity of sufficiently small material, or that there actually was little or no increase in the size of such of that material as may have been present.

$65622-38-8$ 


\section{MICROSCOPIC EXAMINATION}

Microscopic examination showed that after heating the samples, nearly all of the calcium sulfate samples were composed of extremely small crystals ( 0.5 to 2.0 microns in diameter) possessing random orientation in aggregates having the shape of the original gypsum particles. These crystals were so small that their optical properties, other than an approximate mean refractive index, could not be determined. In general, the refractive index was raised by heating.

A sample maintained at $900^{\circ} \mathrm{C}$ for 5 days was, however, composed of medium sized (5 to 10 microns in diameter) tabular crystals, the optical character and refractive indices of which agreed with those of natural anhydrite. The increase in crystal size suggests that perhaps a similar change occurs at lower temperatures, even though not reflected in the X-ray patterns. Fricke, Schnabel, and Beck [33] found a maximum change in heat of solution in $\mathrm{HCl}$ of $\mathrm{Mg}(\mathrm{OH})_{2}$ of 850 $\mathrm{cal} / \mathrm{mole}$, which they attributed to surface changes. This corresponds to approximately $14 \mathrm{cal} / \mathrm{g}$, or very nearly the same as the maximum change that in this work cannot be ascribed satisfactorily to a change in the content of soluble anhydrite of a sample of $\mathrm{CaSO}_{4}$. It seems probable that surface change caused by crystal growth contributes to the change in heat of solution of anhydrous $\mathrm{CaSO}_{4}$, although from present data its effect cannot be disentangled from that of the change in soluble anhydrite content.

\section{HEAT OF HYDRATION AND TRANSITION}

The heats of hydration of the various forms of calcium sulfate may be calculated from the heats of solution. To do so, however, it is necessary to know the heat effect of the water of crystallization of the hydrates. Interpolation of Rossini's data [34] for hydrochloric acid gives the value $17 \mathrm{cal} / \mathrm{mole}$ for the partial molal heat content of water in 2.09 molal $\mathrm{HCl}$. This represents the heat effect of adding water to the hydrochloric acid solution, provided that no dilution occurs, a condition approximated when the $0.42 \mathrm{~g}$ of water of crystallization contained in the gypsum sample is added to $640 \mathrm{~g}$ of acid solution. When $0.42-\mathrm{g}$ samples of water were used as the calorimeter sample the values 14 and $19 \mathrm{cal} / \mathrm{mole}$ were obtained. These agree as well as could be expected with Rossini's value, which was used in the calculations.

The following thermochemical equations may be written, using the heats of solution. The values given are those of $\Delta H$, the increment in the heat content, that is, the minus sign indicates evolution of heat. In all cases where the expression "soln" appears, the aqueous solution 0.017 molal $\mathrm{CaSO}_{4}$ and 2.09 molal $\mathrm{HCl}$ is indicated. Thus, from the data on the heat of solution, the heat of hydration of hemihydrate to gypsum becomes:

$$
\begin{array}{ll}
\mathrm{CaSO}_{4} \cdot 1 / 2 \mathrm{H}_{2} \mathrm{O}(\mathrm{c})=\mathrm{CaSO}_{4} \text { (soln) }+1 / 2 \mathrm{H}_{2} \mathrm{O} \text { (soln), } & \Delta H=+1,604 \pm 25 \mathrm{cal} \\
\mathrm{CaSO}_{4} \text { (soln) }+2 \mathrm{H}_{2} \mathrm{O} \text { (soln) }=\mathrm{CaSO}_{4} \cdot 2 \mathrm{H}_{2} \mathrm{O}(\mathrm{c}), & \Delta H=-5,678 \pm 11 \\
11 / 2 \mathrm{H}_{2} \mathrm{O} \text { (liq) }=11 / 2 \mathrm{H}_{2} \mathrm{O} \text { (soln), } & \Delta H=-25 \\
\mathrm{CaSO}_{4} \cdot 1 / 2 \mathrm{H}_{2} \mathrm{O}(\mathrm{c})+1 \frac{1}{2} \mathrm{H}_{2} \mathrm{O}(\text { liq })=\mathrm{CaSO}_{4} \cdot 2 \mathrm{H}_{2} \mathrm{O}(\mathrm{c}), \Delta H=-4,099 \pm 27 \text { cal. }
\end{array}
$$

Similarly, the values $\Delta H=-6,991 \pm 19$ and $\Delta H=-3,989 \pm 16$ calories per mole are found for the heat of hydration to gypsum of $\mathrm{CaSO}_{4}$ prepared at 75 and $1,000^{\circ} \mathrm{C}$, respectively. From the values 
of the heats of solution the heat of transition of soluble anhydrite to natural anhydrite is calculated to be $\Delta H=-3,002 \pm 22 \mathrm{cal} / \mathrm{mole}$.

It is felt that rounding the results to the nearest 10 cal gives values that are reasonably certain.

It is likely that the transition from the unstable or soluble anhydrite prepared in this investigation to the stable or natural anhydrite begins as soon as there is any of the unstable modification formed, and that it proceeds simultaneously with the continued dehydration of the remaining hydrated material. If such is the case, soluble anhydrous calcium sulfate is a mixture of the stable and unstable forms and the energy level corresponding to the pure unstable form is never reached. The highest heat of solution obtained is, consequently, to be considered lower than the true value since it is entirely possible that if the pure substance were prepared it would have an appreciably higher heat of solution. Hence, the heats of hydration and transition of soluble anhydrite presented here are to be considered minimum rather than the real values.

When gypsum having a heat of solution of $-33.06 \mathrm{cal} / \mathrm{g}$ is heated it loses water with the formation of hemihydrate, the heat of solution of which is $-11.05 \mathrm{cal} / \mathrm{g}$. The hemihydrate on further heating will be converted to soluble anhydrite with a positive heat of solution $(+9.41$ or more cal/g) and this in turn will be transformed to natural anhydrite having a negative heat of solution, $-12.67 \mathrm{cal} / \mathrm{g}$. Since hemihydrate and soluble anhydrite are unstable intermediate products in the transformation of gypsum to natural anhydrite, the relative amounts of these constituents in the heated material will depend largely upon the temperature and time of heating. Even before the hemihydrate has been completely transformed to soluble anhydrite the transformation of soluble anhydrite to natural anhydrite may be well under way. The variable and low results of previous investigators can be partially explained by assuming that the material they used contained variable amounts of the stable and unstable anhydrites and, further, by either or both the length of time required to complete direct hydration or solution (in water) in the calorimeter and the accuracy of measurement of temperature differences. It seems then, that the earlier determinations of the heat of hydration of the forms of calcium sulfate were performed under handicaps to which the present investigation was not subject and that the values here presented may be considered reliable.

\section{SUMMARY}

The heats evolved in the hydration to $\mathrm{CaSO}_{4} \cdot 2 \mathrm{H}_{2} \mathrm{O}$ at $25^{\circ} \mathrm{C}$ of $\mathrm{CaSO}_{4} \cdot 1 / 2 \mathrm{H}_{2} \mathrm{O}$ prepared by treating gypsum with steam in the autoclave, and of $\mathrm{CaSO}_{4}$ prepared by heating gypsum at $1,000^{\circ} \mathrm{C}$, have been determined and found to be 4,100 \pm 30 and $3,900 \pm 20 \mathrm{cal} / \mathrm{mole}$, respectively. The heat evolved in the hydration to $\mathrm{CaSO}_{4} \cdot 2 \mathrm{H}_{2} \mathrm{O}$ of soluble anhydrite prepared by dehydrating gypsum at $75^{\circ} \mathrm{C}$ is not less than $6,990 \mathrm{cal} / \mathrm{mole}$. During the progress of this work no indications were found of more than two anhydrous forms of calcium sulfate; soluble anhydrite, and a modification formed rapidly at high temperatures, the latter being identical with natural anhydrite. The heat evolved in the transition of soluble anhydrite to natural anhydrite is not less than $3,000 \mathrm{cal} / \mathrm{mole}$. 
The authors are indebted to F. B. Hornibrook, who did the preliminary work on this problem, and to $\mathrm{H}$. Insley and H. F. McMurdie, who made the X-ray patterns and assisted with the microscopic examination of the materials.

\section{REFERENCES}

[1] Van't Hoff, et al., Z. physik. Chem. 45, 257 (1903).

[2] Jung, Z. anorg. allgem. Chem. 142, 73 (1925).

[3] Ramsdell and Partridge, Am. Mineral. 14, 59 (1929).

[4] Caspari, (a) Nature 133, 648 (1934); (b) Proc. Roy. Soc. (London) [4] 155, 41 (1936).

[5] Feitknecht, Helv. Chim. Acta 14, 85 (1931).

[6] Onorato, Periodico Mineral. 3, 138 (1932).

[7] Gallitelli, Periodico Mineral. 4, 1, 132 (1933).

[8] Weiser, Milligan, and Ekholm, J. Amer. Chem. Soc. 58, 1261 (1936).

[9] Weiser and Milligan, J. Amer. Chem. Soc. 59, 1457 (1937).

[10] E. Posjnak, Private communication.

[11] LaCroix, Compt. rend. 126, 360, 553 (1898).

[12] Gaubert, Bul. soc. franç. minéral. 5\%, 252 (1934).

[13] Jolibois, Bul. soc. chim. 41, 117 (1927).

[14] Chassevent, Ann. chim. \%, 43 (1927).

[15] Grahmann, Z. anorg. Chem. 81, 257 (1913).

[16] Budnikov and Gulinova, Ann. secteur anal. phys.-chim. Inst. chim. gén. (USSR) 8, 357 (1936).

[17] Thomsen, Thermochemische Untersuchungen, III, 249 (Barth, Leipzig, 1886).

[18] de Forcrand, Bul. soc. chim. 35, 781 (1906).

[19] Mixter, Am. J. Sci. 40, 23 (1915).

[20] Chassevent, Compt. rend. 179, 44 (1924).

[21] Winchell, The Microscopic Characters of Artificial Minerals, p. 226. (John Wiley \& Sons, London, 1931).

[22] Larsen and Berman, The Microscopic Determination of the Nonopaque Minerals. Bul. 848, U. S. Geological Survey (1934).

[23] Woods, Steinour, and Starke, Ind. Eng. Chem. 24, 1207 (1932).

[24] Biddle and Kelly, Proc. Am. Soc. Testing Materials 33, pt. II, 571 (1933).

[25] Stenzel and Morris, Ind. Eng. Chem., Anal. Ed. 6, 246 (1934).

[26] White, The Modern Calorimeter, p. 42 (The Chemical Catalog Co., New York, N. Y., 1928).

[27] Rossini, Chem. Rev. 18, 233 (1936).

[28] Marchal, J. chim. phys. 23, 38 (1926).

[29] Wells and Taylor, J. Research NBS 19, 215 (1937) RP1022.

[30] Budnikov, Z. anorg. allgem. Chem. 15\%, 87, (1927).

[31] Laschenko and Kompanskii, J. Russ. Phys. Chem. Soc. 60, 579 (1928).

[32] Burger, Physica 2, 114 (1922).

[33] Fricke, Schnabel, and Beck, Z. Elektrochem. 42, 881 (1936).

[34] Rossini, BS J. Research 9, 679 (1932) RP499.

[35] Olson, Compt. rend, 179, 1041 (1924).

Washington, March 25, 1938. 